\title{
Access to Justice: A Concept in the Light of the European and American International Systems
}

\section{Makowiecky Salles B ${ }^{1 *}$ and Márcio Cruz $\mathbf{P}^{2}$}

${ }^{1}$ Doctor in Legal Science from the Stricto Sensu Graduate Program in Legal Science, PPCJ/ UNIVALI, University of Perugia, Italy

${ }^{2}$ Doctor in State Law from the Federal University of Santa Catarina, Italy

*Corresponding author: Bruno Makowiecky S, Doctor in Legal Science from the Stricto Sensu Graduate Program in Legal Science, PPCJ/UNIVALI, University of Perugia, Italy, Email: brunomakosalles@terra.com.br
Investigation Paper

Volume 4 Issue 3

Received Date: June 19, 2021

Published Date: July 27, 2021

DOI: $10.23880 / a b c a-16000188$

\section{Abstract}

This short article aims to evaluate Access to Justice, stablished in important international documents, in the light of doctrinal contributions and the perception of the European and Inter-American Courts of Human Rights. In the end, the content studied is considered for the formulation of a legal concept of Access to Justice in the view of international systems.

Keywords: Access to Justice; International Systems; Concept

\section{Introduction}

Given the multiplicity of meanings of the expression Access to Justice (lato sensu) and the richness of the various aspectos involved, it has alredy been observed that "Il est paradoxalement plus aisé de définir ce que n'est pas le droit d'áccès au juge" Donier V, et al. [1]. Access to Justice is one of those kaleidoscopic expressions, reflecting an idea that "draws the mind to a multitude of questions about the sources of injustice and the legal systems around the world that have developed to help provide an avenue for redressing a wrong". While some take narrow views, others include almost all of the problems in the justice systems.

This short article, based on bibliographic research and using an inductive method, aims to evaluate Access to Justice, stablished in important international documents, in the light of doctrinal contributions and the perception of the European and Inter-American Courts of Human Rights. In the end, the content studied is considered for the formulation of a legal concept of Access to Justice in the view of international systems.

\section{Access to Justice in International Systems}

Access to Justice is stablished in important international documents, such as the Universal Declaration of Human Rights (art. $8^{\circ}$ ), the European Convention on Human Rights (art. $6^{\circ}$ e 13), the American Convention on Human Rights (art. $8^{\circ}$ e 25) and the African Charter on Human and Peoples Rights (art. $7^{\circ}$ ), among others. The international standards, although not identical, exercise a "funzione unificante" related to the criation of a "sostrato comune di valori condivisi tra i diversi Paesi" Osti A, et al. [2] in terms of Access to Justice.

Under the lens of contemporary international law, Access to Justice is classified as a human right that must "prima di tutto essere assicurato nell'ambito dell'ordinamento giuridico interno dello Stato in cui è avvenuta la lesione di un diritto" Francioni F, et al. [3]. If its not sufficiently guaranteed at the national level, arises the "right of individual petition directly before international humans rights tribunals 
(such as the European, Inter-American and, more recently, African Courts)". This indicates that "the jurisdictional solution constitutes the most perfected and evolved means of international protection of humans rights" Cançado Trindade AA, et al. [4]. Access to Justice, therefore, is an essential ingredient for improving human rights protection and conflict resolution systems.

The European Court of Human Rights has given an evolutionary interpretation to the text of the Convention (art. 6), which is based on Anglo-Saxon law and the values of procedural justice and equity. The Convention is limited to enunciating the principles of a fair process, without protecting substantial positions. However, this lack was overcome in the mid-1970s Osti A, et al. [2]. The Court began to conceive Access to Justice as a right that "ocuppe une place si èminente" (ECHR, pp: 11) [5], the violation of which can be denounced. According to the parameters of the case-law, the intervention presupposes a dispute over a right that is, at least on arguable grounds, recognized in domestic laws. The dispute still "must be genuine and serious; it may report not only to the actual existence of a right but also to its scope and the manner of its exercise" (ECHR, pp: 45) [6]. In addition, must be included principles such as pre-procedural and procedural legal assistance, equity, publicity, reasonable duration and reasons giving Osti A, et al. [2], and the outcome must be decisive for the enjoyment of the right.

For the Inter-American Court of Human Rights, Access to Justice is "uno de los pilares basicos no sólo de la Convención Americana, sino del proprio Estado de Derecho en una sociedad democratica em el sentido de la Convención" (ICHR, pp: 52) [7]. It is marked by its service dimension and its duty to provide adequate resources to protection rights [8]. Also, the States have the primary task of promoting Access, observing an interaction between the parameters established by international law and the internal rules. The intervention of the Court occurs after domestic remedies have been frustrated Mendonca JJFS, et al. [9], despite the restrictive interpretation given to this subsidiary character Ramos AC, et al. [10]. Emphasis is placed on the duty of effectiveness of the process, under penalty of violation of the conventional rules [8]. The decisions of the Court may invalidate internal acts of the States, as well as impose the duty to repair the damages. Judicial protection is based on pillars such as the mandatory jurisdiction of the Court and the enforceability of its decisions at the domestic level [8].

The supranational courts and the doctrine share the perception that Access to Justice is classified as a human right. Faced with terminologies such as 'effective remedy', commonly used in treaties and decisions, it is also understood that Access do Justice (lato sensu) guarantees more than Access to the Judiciary or the simple fact of being before a
Court, but brings together the due process of law and its guarantees [4]. It also covers the idea of Access to Rights in extrajudicial channels and other ways to repair an illegal act [3], such as the ADRs. In addition, the main purpose is to ensure the effectiveness of substantial human rights, even if this effectiveness does not occur through the judicial system [8]. The judicial path is ordinarily seen as an instrument for the protection of other rights and not as an autonomous right [11], except when it is being discussed the possibility to access effective judicial or extrajudicial protection, or else to have access to legal assistance for criminal defense [3].

However, it is obvious that the Courts does not recognize an absolute right (ECHR, pp: 24) [12,13]. Even if prevail the idea of "azionabilità" of rights before the International Courts [11], or "une tendance plutôt favorable àl'effectivité de ce droit" [1], there is a typology of substantial and procedural limitations, which are accepted in consideration to other rights or public interests, as long as they have a legitimate scope and keep proportionality between the means employed and the ends pursued [2]. Among these restrictions, one can mention the filters based on the chance of success Osti A, et al. [2], the validity of reasonable time limits for postulations, the inability to sue certain people under certain circumstances, as in the case of diplomatic immunity, or, still, barriers against abusive and vexatious actions that would collapse the judicial system [3]. Finally, the Courts reserve a subsidiary role and institute some administrative and jurisdictional filters for its performances, making it with the objectives of keeping with the States the primary duty to guarantee Access to Justice and to manage the high flow of processes it receives [2].

\section{Conclusion}

This short article assessed the right of Access to Justice, entrenched in important international documents, in the light of doctrinal contributions and the perception of the European and Inter-American Courts of Human Rights.

Based on the content exposed and adding a few ideas, Access to Justice (lato sensu) can be conceptualized as a human right at the international level and a fundamental right at the domestic level, commonly established in the form of a principle, but which can also be implicit in legal systems. It has its own value, which is combined with an instrumental function and with a complex content. It encompasses State and private actors behaviors, but also incorporates aspects of freedoms and participation rights. It is specified (stricto sensu) in the possibilities of:

- Access to Courts for judicial protection, through a fair trial and with all the guarantees of the due process, such as impartiality, reasonable duration, motivation of decisions, publicity and others, and 
- Access to Rights in extrajudicial spheres, in terms of information, advice and effective alternative methods of conflict resolution. All these notions interacts and generate a non-absolute content that depends on the interpretative activity, in the tension between normativity and factual limitations.

\section{References}

1. Donier V, Lapérou-Schneider B, Gerbay N, Hourquebie F, Icard P (2003) Propos introductive. Access to the judge: research on the effectiveness of a right. Brussels: Bruylant, pp: 21-50.

2. Osti A (2016) Theory and practice of access to justice: a comparison between national and foreign legal systems. Milan: Giuffrè Editore.

3. Francioni $\mathrm{F}$ (2009) The right of access to justice in general international law. Access to justice of the individual in international and European Union law. Milan: Giuffre, pp: 3-44.

4. Cançado Trindade AA (2011) The access of individuals to international justice. New York: Oxford University Press.

5. (1970) European Court of Human Rights. Delcourt vs.
Belgium. n. 2689/65. Strasbourg.

6. (2006) European Court of Human Rights. Inadmissibility decision concerning France.

7. (2006) Inter-American Court of Human Rights. Caso López Álvares vs Honduras. San Jose.

8. Mendonca JJFS (2016) Equitable access to law and justice. São Paulo: Almedina.

9. Oliveira CL, Maeoka E (2009) The Inter-American Court of Human Rights and the promotion of access to justice. Scientia Juris 13: 229-253.

10. Ramos AC (2013) International human rights process. São Paulo: Saraiva.

11. Lenzerini F, Mori R (2009) Access to justice for migrants at risk of violating fundamental rights. Access to justice of the individual in International and European Union law. Milan: Giuffré, pp: 149-174.

12. (2021) European Court of Human Rights Case of $Z$ and Others vs. The United Kingdom. n. 29392/95. Strasbourg.

13. (1975) European Court of Human Rights. Golder vs. United Kingdom. n. 4451/70. Strasbourg. 